\title{
Response of Vietnamese Private Enterprises’ Leader under Global Financial Crisis: From Theoretical to Empirical Approach
}

\author{
Phung Xuan Nha ${ }^{1} \&$ Le Quan ${ }^{1}$ \\ ${ }^{1}$ Vietnam National University, Ha Noi, Vietnam \\ Correspondence: Phung Xuan Nha, Vietnam National University, Ha Noi, Vietnam. E-mail: nhapx@vnu.edu.vn
}

Received: January 21, 2014

doi:10.5539/ass.v10n9p26

Accepted: March 10, $2014 \quad$ Online Published: April 29, 2014

URL: http://dx.doi.org/10.5539/ass.v10n9p26

\begin{abstract}
The recent problems of bankruptcies and ineffective performance under the impact of the recession of 2008 - 2009 had raised questions about the importance of leadership in Vietnamese private enterprises. This paper presents the results of an empirical study that explores leaders' decisions during 2008-2012 to help their business survive; their forecasts and expectations for when the recession was over and the competencies needed for successful leadership in times of recession. The survey sample was composed of 478 CEOs and 561 senior managers in Vietnamese private enterprises. The results indicate almost respondents of the surveyed leaders agreed about slow economic recovery and the moderate level of leadership and management performance were forecasted. Struggling with impact of recession, the surveyed leaders agreed that adapting to an increasingly complex and unpredictable business environment is essential and they must be more flexible. Especially, amongst the 14 factors, sustainability, working enthusiasm and willingness to take risk appear to be more responded in what leaders should do in times of economic downturn. Meantime, it also can be concluded from the survey of senior managers about leader's needed competences that all values are under 4.0, which means no leadership competencies or skills is evaluated as good or excellent.
\end{abstract}

Keywords: leader, leadership, Vietnam, private enterprises

\section{Introduction}

The explosion of private enterprises (Note 1) in Vietnam in the last decade has been associated with institutional reforms for the private sector (Note 2), the integration of Vietnam in the global economy, and with the opportunity to access inexpensive capital.

In Vietnam, the concept of the private sector began to be recognized since Doi moi (renovation) in 1986 (Cuong el al., 2008). However, it was not until four years later, when the Law on Private Enterprises and the Companies Law were enacted that we have witnessed the birth and growth of private enterprises, especially in the South of Vietnam. In the later stage of Doi moi, large private enterprises were often active in the field of consumer goods production to meet the huge demand from the local market at the time. Meantime, some of the first foreign banks (ANZ, BNP) came to Vietnam in 1990 and the private sector began to take off. In just 5 years from 1993 to 1997, there were nearly 20 thousand private enterprises newly established (Note 3). At this stage, the first generation of entrepreneurs and business leaders of Vietnam was developed. However, opportunities always come with challenges. The battle to compete with foreign competitors has forced numerous businesses to go bankrupt or to sell their businesses.

The normalization in relations with the United States and in the joining of ASEAN in 1995 Vietnam showed that it had entered the international integration. The fact that the Law on Enterprises was amended 2 times in 1999 and 2005 stimulated young people to have the ambition to take part in and to lead. From then, the strength of the economy was raised and officially booming when the stock market and several commercial banks were born and foreign capital flowed torrentially into Vietnam from investment funds. By this way, private enterprises (Note 4) had opportunity to access easily to abundant capital loans. 
Asian Social Science; Vol. 10, No. 9; 2014

ISSN 1911-2017 E-ISSN 1911-2025

Published by Canadian Center of Science and Education

Statistics showed that during 2005-2011, the number of new non- state companies rocketed from 98.833 to 312.433 enterprises, equivalent to 216\% increase. Compared to 2000, the number of newly established enterprises in 2011 rose approximately 497\%, compared with the figure in 2000 of about 53.241 enterprises (Note 5).

Discussing the characteristics of this sector, its employment was almost considered as family business or village scale, with an average number of 30 employees per enterprise, usually unskilled ones. In comparison, the average number of employees of a FDI enterprise was more than 300 and that of a State-owned enterprise was more than 500 (Nguyen, 2011). Other characteristic of non-state enterprises is that they have been operating at smaller capital investment. The average amount of capital in period 2005 - 2011 was only in the range from 682,3 to 7.015,8 trillion VND, which is much lower than that of State enterprise and FDI enterprises. Regarding size of employment and of capital resource, enterprises in this sector are often small and medium ones (Note 6). Thanks to smaller employment and capital scales, not only recruitment but also management process in this kind of enterprises could be done easily and much simply. From above features, establishing a private enterprise became easier than other kinds, the number of non-state enterprise was therefore increasing over time.

Private sector has strongly proven their vital impacts on Vietnam economy. In the last few years and even under the economic recession, the private sector has successfully implemented its social goals, creating greater employment, contributing to "poverty reduction", tendering economic development (Nguyen, 2011). In more details, the increase in the quantity and capital size of private enterprises is first presenting the improved role of the domestic capital in the economy and how good Vietnamese effort is in utilizing available capital from citizens. From that, all achievements of private sector are associated with the facilitation of Vietnam economy. Private sectors recently contributed more than $30 \%$ of the net turnover of the whole country. In 2005, there was 833,8 trillion VND in private sector's net turnover, accounting for nearly $30 \%$. Its share was about to rise by more than $20 \%$ in 2011 , in which private sector contributing about $54 \%$ of total net turnover in Vietnam. Besides, there was a big fraction of our labor force working in this sector, increasing from 46,4\% in 2005 to $61,7 \%$ in 2011. The total output of Vietnam rose from 1588,6 in 2005 to 2412,8 trillion VND in 2011 (1.5 times in constant 2010 price), thanks to the relatively great contribution of the non-state sector, with its range being from $47,2 \%$ to $49,34 \%$. All above outcomes are explained for how crucial the private sector is in supporting pace of economic growth in Vietnam in the last decade (Note 7).

However, private enterprises remained a series of shortcomings which made their "health" unstable, such as small production scale, poor ability to mobilize and save capital, weak management skills, low-qualified workers, and lack of technological know-how (Nguyen, 2011). All these weaknesses have contributed to their low competitiveness recently, especially when the recession time comes.

Looking back at Vietnam in 2008 - 2009, financial and real estate bubble-breaking led to the collapse of a series of businesses. This recession touched the global economy, unlike the previous recessions, and the financial sector was identified as the main source of the crisis (Athey, 2009). It is marked out by its globally deep influence, the structural implications it has for the world's financial systems and investment regimes, and finally by the profound hardship in many parts of the world (Clark, 2009). Until now, after 5 years, the collapse has still had no sign of stopping. Consequently, in the last 5 years, the GDP growth of Vietnam has twice reached the bottom (the first time in 2009 when GDP growth reached 5.3\% and the second time in 2012, when GDP growth was only 5.03\%) (Note 8). These figures can be considered as signs of the likely prolonged duration of the crisis, and our economy might take longer time to tender recovery.

In addition, when the economy fell into recession, other monetary policies was also enacted to maintain economy stable, including tighter lending conditions and declining purchasing power, private enterprises have therefore gone bankrupt or suspended operation. And only in the context of the crisis, the leaders' spirit and their capabilities are most revealed (Le, 2012).

According to a survey of General Statistics Office of Vietnam in 2012, from 01/01/2011 to 01/4/2012, all bankrupt accounted for $8.4 \%$, of which the non-state bankrupt enterprises took the highest rate (9.1\%) (Note 9).

In order to deal with the collapse of private sector in Vietnam, many scholars, researchers and even business leaders agree that the key to success or failure in the past has been leadership capability and the crucial role of leadership. Clark (2009) emphasized the solution of "a need for leadership internationally, nationally, and locally". 
Additionally, the current global recession is a crucial moment for local leaders. In their research, there were lessons from around the world involving how leaders should respond in places adversely affected by crisis. This research again, emphasized leader's necessary ability to fight the economic downturn and challenges. To some extent, not only in prosperous time but also in economic downturn would the role of private sector be recognized; therefore, to facilitate private enterprises to overcome a crisis, leadership is considered as the vital factor.

By empirical approach, this study aims to show how leaders of Vietnamese private enterprises responded in the context of global recession and confronts their responses with theoretical framework. Specifically, leaders' expectations in economic prospects, self-assessed leadership performance, main challenges and top priorities under recession time as well as leader's needed competencies are going to be investigated. From the survey's results, the study can be used as references for policy-makers to give initial assessment on the leadership in Vietnamese private enterprises and subsequently recommend some solutions so as to improve leadership in those enterprises.

There are many researches discussing about leadership and the expected responses of the leaders. A closer access to leaders' insight themselves have received little attention. In other words, none of the previous studies have concentrated on the perceptions of leaders in dealing with recession, although leaders are believed to be the one who gives final decisions that intrinsically affect business performance. The role of leaders and the improvement of leadership become much more prominent, especially in post-crisis period. Thus, this survey is expected to narrow this gap and contribute to the extension of other research.

Structure of the paper is as follows. The next section will be the literature review which includes some previous studies relevant to the topic. Subsequently, the paper discusses about survey methods, and finally the survey results and implications conclude the paper.

\section{Literature Review}

\subsection{Leader, Leadership and Role of Leadership}

Leadership is different to management. Management is often known as a maintenance activity, concerned with technical implementation of policies and procedures while leadership often links with shaping others' goals, broader values and sense of purpose, especially in relation to change and mobilizing staff effort by engaging, inspiring and supporting individual and team performance (Cuban, 1988). Leadership can be conceptualized as a collective phenomenon where different individuals contribute to the organization (Pettigrew \& Whipp, 1991). Leadership competencies mention to the knowledge, skills, or abilities that assist one's ability to perform a task (Boyatzis, 1982).

In a crisis situation, leadership is collective and dynamic, and it requires perception and sense-making skills by leaders in order for them to determine appropriate courses of action (Weick, 1988). During crisis, leaders should focus on decision making, communication, creating organizational capabilities, sustaining an effective organizational culture, managing multiple constituencies, and developing human capital (Bolman \& Deal, 1997, Wooten \& James (2008)). Therefore, the leadership competencies they need are related to managing the operational, strategic, and human resource functions, and also financial functions (Denis et al., 2001, Wooten et al., 2008).

Effective leaders are leaders who manage to encourage staff to actively engage in knowledge acquisition and the formulation of strategies to resolve the crisis (Dutton \& Jackson, 1987). However, in most cases leaders are not prepared to manage the crisis (Garcia, 2006). As business environments change and grow increasingly complex, it is important that leaders develop a set of skills that will help them prevent and effectively respond to crisis (Burnett, 2002).

\subsection{Role of leadership competencies}

Research of Dai, Tang \& De Meuse (2007), Orr \& Sack (2010) stated that the leadership competencies most link with performance and potential vary by level. At the highest leadership level in an organization, leaders are showing themselves to be master problem solvers in the crisis time. They seem to be ready to encounter and study from challenges and high stakes situations. Moreover, the leader can realize the importance of bringing others as long as they lead people through tough situations in a determined and courageous way. In a changing environment, the ability to operate the business and execute work effectively in a challenging environment, getting the work done by 
Asian Social Science; Vol. 10, No. 9; 2014

ISSN 1911-2017 E-ISSN 1911-2025

Published by Canadian Center of Science and Education

developing others, carefully tracking progress, and managing resources and processes efficiently have all increased in importance (Orr \& Sack, 2010).

However, Orr \& Sack (2010) also indicated that leaders are lacking a creative ability - the way to incubate new ideas that could transfer to the business situation. Along with the lack of creativity, there seems to be a lack of inspiration, which could bring even more negative impacts on their employees in tough times.

\subsection{Recession's impacts on leadership}

As a matter of fact, economic history teaches that after every recession there is a recovery and there is always opportunity in crisis. The word "crisis" in Chinese is composed of two characters. One represents danger and the other represents opportunity (Note 10).

The economist Drucker always sees crisis as providing great opportunities for leaders. According to him, doing nothing (or not enough) in a time of crisis may sink companies. Indeed, he states that there are no risks, only opportunities and in order to transform the risk into an opportunity the first step is to decide what to divest, meaning to make a clear decision on what to withdraw and on what to concentrate.

One of the most important things to help to seize opportunity from crisis is confidence in economic conditions and expectations about the future. These are considered as two key drivers for SMEs to continue to invest in and grow their business (Chow \& Dunkelberg, 2011). The research shows that in a recession time, business owners are considerably more optimistic than employees (Storey, 2011, Price, Rae \& Cini, 2013) and there is always the potential for entrepreneurial spirits to pursue opportunities counter-cyclically by creating their own confidence and bootstrapping resources (Rae et al., 2012).

However, recession could have negative psychological impacts on leaders and thus lead to inadequate actions. Egan \& Tosanguan (2009) indicated that entrepreneurs may 'overreact' in times of economic uncertainty because of the psychological stress of the uncertainty itself.

\subsection{Coping strategies in recession}

According to many authors, SMEs have less control over their external environment when compared with larger firms (Smallbone et al., 1999) and SMEs perceive recessions as "an externally controlled condition over which they have no control” (Stone, 1975:1; Price et al, 2013:2). To be able to overcome a crisis, SMEs must have a strategy.

SMEs' strategies could be divided in two main groups: One strategy is cost-cutting to survive in the recession and focus on growth to retain capacity when the recession is over. A cost-cutting approach is evident in the construction and manufacturing sectors and includes downsizing the workforce, reducing products, reducing stock, and freezing pay (Price et al., 2013). The other strategy is a growth approach which means offering new or improved products, competing on price, and acquiring other firms that have been weakened by the recession (Stone, 1975; Price et al, 2013). Regarding the growth strategy, a study of SMEs' responses to the 2008-2009 recession showed that product diversification, including the introduction of new goods/services and attraction of new customers, was one of the most effective way to help SMEs respond to recession (Kitching, Smallbone, Xheneti \& Kasperova, 2011).

A framework provided by Hofer (1980) suggests four possible actions to cope with economic duress: (i) cost-cutting strategies (Note 11); (ii) combination effort strategies (Note 12); (iii) revenue-generating strategies (Note 13); (iv) asset-reduction strategies (Note 14). According to Egan et al (2009), the empirical evidence in support of Hofer's framework is partially mixed. In the time of the economic crisis, some scholars haveindicated to audiences the costcutting strategies to dominate the strategic response of entrepreneurs (Beaver, 2007; Beaver \& Ross, 1999; Churchill \& Lewis, 1984); some authors have found revenue-generating strategies as another choices (e.g. Latham, 2009); and others still have mentioned combination effort strategies to be a marker of high performing firms (e.g. Kambil, 2008).

Lovelock (1997), on the other hand noted two strategies emerging from a psychological perspective, rather than being defined by action: (i) reactive strategies-common reaction is fearful cost-cutting, and price promotions to 
Asian Social Science; Vol. 10, No. 9; 2014

ISSN 1911-2017 E-ISSN 1911-2025

Published by Canadian Center of Science and Education

return lost sales; (ii) proactive strategies - this strategy begin with the idea the best time to prepare for a recession is during a time of prosperity, or even in the period before the business becomes a ruinous business. Proactive strategies can generate revenue, and inturn, firstly, it requires in the potential adversity, and secondly, to find and get some advantages of emerging opportunities when recession comes(Shama, 1993).The empirical evidence linking proactive strategies to improved performance across the economic cycle is substantial (see, e.g. Lester et al., 2008; Pearce \& Michael., 2006; Srinivasan et al., 2005).

\subsection{Research gaps}

The above researches have pointed out the importance of the leader, the leadership and leadership's competence in an organization, particularly in times of crisis, as well as the possible strategy options for leaders to choose from and competencies needed to be further developed in hard times. The findings in those researchers, therefore, are of significance as to which strategies and psychological approach that business leaders should adopt to overcome the adverse situation. Those findings could be good suggestions for all leaders including the Vietnamese ones, although practical application could vary in form for different situations.

Since there has not been any research investigating the response of Vietnamese private enterprise leaders in times of recession, this study aims to provide an insight into response and performance of Vietnamese business leaders in the recession 2008 -2009 and thus, make a suggestion for the leaders about the leadership competencies required in Vietnam under recession's impacts.

This study was to answer the following questions:

1) How did the business leaders evaluate their leadership and business performance in the time of recession?

2) What were the challenges that business leaders face?

3) What were the leadership competencies that the business leaders consider important in times of recession?

4) How did senior managers assess their business leaders’ competencies?

\section{Methodology}

\subsection{Sampling method}

The target sample of the present study includes business leaders (CEOs) and senior managers in Vietnamese private enterprises. The sample is divided into two groups (business leaders and senior managers) which were surveyed separately.

In the first survey, the objective was conducted to find the business decisions that the leaders made during 20092012 to make their companies survive (especially during 2011- 2012 when the full-blown crisis). And the other purpose was evaluate their forecast and expectations when the recession was over. Furthermore, the first survey was conduct to get the leader's ideas about thier competencies needed for successful leadership in times of recession.

In the second survey, senior managers were required to evaluate their leaders' competencies. Given that leadership is different from management, which is concerned with technical implementation of policies and procedures (Cuban, 1988), we included senior managers in this survey to take more ideas and precise assessment of their leaders' quality.

E-invitations with online-based questionnaire were sent separately to the members of Vietnamese Young Leaders Association (more than 1000 CEO of SMEs) and of HR Link (more than 10.000 HR Managers). The duration of the survey was nearly 2 months. The total of 478 CEO and 561 senior managers participated in the study, with 478 valid answers from business leaders and 561 valid answers from senior managers in total.

\subsection{Survey instruments}

The items in the questionnaire were classified with regard to 4 issues (top priorities in times of recession, leadership and management performance,leadership competencies needed and evaluate the leader's competence by senior managers). Responses to each questions were measured on a five-point scale, ranging from $1=$ Strongly Disagree to 5 = Strongly Agree.

\subsection{Demographic profiles of the respondents}


Asian Social Science; Vol. 10, No. 9; 2014

ISSN 1911-2017 E-ISSN 1911-2025

Published by Canadian Center of Science and Education

Male leaders and managers comprise the majority of the surveyed respondents. Leaders had a fairly high level of education. More than half of the leaders and managers were at the university or college level. Notably, over $35 \%$ of the leaders had postgraduate training. This result was highly encouraging compared to previously published surveys of education leaders of non-state enterprises (Le, 2011). However, it is also noted that this survey sample was mostly from big cities and would not be nationally representative.

Regarding ages, leaders surveyed have an average age of 38.6 years. The oldest was 60 years old and the youngest 19 years old. Thus, the average age of the leaders of non-state enterprises is relatively young. Over $70 \%$ of business leaders participated as business operators before the age of 35 .

Regarding general management experience (managerial participation), 34\% of the leaders had under 5 years of experience in management. The number of leaders having management experience from 5 to 10 years was $42.8 \%$ and $22.6 \%$ for those with 10 years of experience. Similarly, leadership experience of leaders participating in operational executives was commonly from 3 to 5 years (44.7\%) and 5 years (29.6\%). Up to $24.5 \%$ of new business leaders were involved in executive committees for at least three years.

In regard to the types of businesses, the SMEs studied were diverse in terms of business area, legal form, turnover and number of employees.

\section{Results and Analysis}

In this paper, we present the findings and analysis of the two surveys: self-evaluation by business leaders and assessment by senior managers in Vietnamese private enterprises. The findings of this study are analyzed under some main headings: 1) Leadership and management performance; 2) The challenge of recession; 3) Top priorities in times of recession; 4) Leadership compet encies needed; and 5) Leaders' competencies assessed by senior managers.

\subsection{Leadership and management performance}

In order to evaluate the leadership and managemenet performance, respondents were required evaluate 14 item include: (1) business performance, (2) leadership and management performance; (3) Human resource management; (4) Financial management; (5) Strategic management; (6) Risk management; (7) Maketing; (8) Customer relationship management; (9) Partner development and management; (10) Product management; (11) Quality management; (12) Increasing operation efficiency in IT; (13) Cost saving and (14) Productiviy.

Overall, the respondents evaluated that all items were at average level (all items were around 3.2 point on average). The results of this section indicate that leadership and management performance are just fewer than 3.250 on the average. Particularly, the leaders showed highly agree with some aspects in leadership and management performance that were cost saving (average at 3.379, standard deviation at 0.714 ); quality management ( average at 3.345, standard deviation at 0.686) and partner development and management (average at 3.289 and standard deviation at 0.772 ).

Interestingly, some important aspects of management such as strategic management, human resource management and financial management were not satisfactory with the average under 3.2. . It means that the leaders were not satisfy with the internal management performance. Particularly, the lowest average score in the survey was recorded by risk management with the average score of 2.974 and standard deviation at 0.882 . It indicated that the risk management in the private enterprises were not attracted by the leaders.

The standard deviations for all items are smaller than 1.0, implying consistencies in the answers given by the respondents.

Table 1. Performance of leadership and management $(\mathrm{N}=408)$

\begin{tabular}{cccccc}
\hline & N & Min & Max & Average & Standard Deviation \\
\hline Leadership and management performance & 462 & 2.00 & 5.00 & 3.240 & .636
\end{tabular}


Asian Social Science; Vol. 10, No. 9; 2014

ISSN 1911-2017 E-ISSN 1911-2025

Published by Canadian Center of Science and Education

\begin{tabular}{cccccc} 
Human resource management & 459 & 1.00 & 5.00 & 3.111 & .764 \\
Financial management & 459 & 1.00 & 5.00 & 3.170 & .722 \\
Strategic management & 459 & 1.00 & 5.00 & 3.118 & .776 \\
Risk management & 456 & 1.00 & 5.00 & 2.974 & .882 \\
Production management & 438 & 2.00 & 5.00 & 3.336 & .715 \\
Quality management & 444 & 1.00 & 5.00 & 3.345 & .686 \\
Cost saving & 459 & 1.00 & 5.00 & 3.379 & .714 \\
\hline
\end{tabular}

Source: Author (2013) Note 15

\subsection{The challenge of recession}

In the crisis situation, business owners have to deal with many challenges. The results of this survey highly agreed with two main challenges were the complexity of business environment (with the average at 4.119) and the risk in changing government policy (average at 3.918). Because in the dynamic environment and the time of crisis, the leaders evaluated two main things as huge threaten for business owners. Furthermore, the challenge was indicated in the organization, the respondents expressed their deep concerns about restructuring of their business to adapt with the complexity of business environment and how can they predict market deman (3.810 on average). As analysis above, in the crisis time, leaders showed their highly concern about the external environment factors. Some challenges as pressure from rising labor costs, less business opportunity received the average level. Thus, in the leader's point of view, they was not highly evaluate those factors as a serious challenges.

Interestingly, the respondents indicated that the short-termed business trend was at least considered as a challenge (rated at only 2.89 on average), the respondents also believed that their products can still satisfy the customer demand in the crisis time (the average at 3.082). Moreover, the leaders also expressed their confidence in their products (product no longer meet market demand with average at 3.082).

Table 2. Challenges of recession $(\mathrm{n}=478)$

\begin{tabular}{lllll}
\hline & N & Min & Max & Average \\
\hline Business environment becoming more complex & 477 & 1.00 & 5.00 & 4.119 \\
Risks of Government policy changes & 474 & 1.00 & 5.00 & 3.918 \\
Business restructuring & 477 & 1.00 & 5.00 & 3.899 \\
Predicting market trends & 474 & 1.00 & 5.00 & 3.810 \\
Pressure from rising labor costs & 477 & 1.00 & 5.00 & 3.698 \\
Less business opportunities & 474 & 1.00 & 5.00 & 3.557 \\
Products no longer meet market demand & 474 & 1.00 & 5.00 & 3.082 \\
Short-termed business trend & 474 & 1.00 & 5.00 & 2.892 \\
\hline
\end{tabular}

Source: Author (2013)

Phung \& Le (2013) also indicated some challenges for business owners in recession such as: high manpower cost, less business opportunities. These result shows that SMEs' leaders have struggled with building competitive advantages of their enterprises and creating innovation in the time of recession. 


\subsection{Top priority action in the time of recession}

In the time of crisis, with the unstable business environment and unpredictable government policies, business leaders must choose some priority actions; the respondents were asked what kind of priority action they should do to help their business overcome the crisis. The results show that some priority actions of the business leaders were restructuring and optimizing of the financial system (282 respondents account for 58.99\%), cutting of the operation costs (47.07\%) and elimination of ineffective operation (44.56\%). In the crisis time, in order to survive, business leaders of Vietnamese private enterprises realized that they must focus on outcomes and efficiency of business in the short term by tight controlling their financial situation.

Interestingly, leaders in private enterprises did not choose downsizing employees as the priority action in the crisis time (15.06\%) although downsizing employees can be evaluated as one of the effective method to cost-cutting. Moreover, they also did choose empowering and managing employee with KPI (20.71\%) and developing excellent human resource $(22.59 \%)$ as the priority actions in the crisis time.

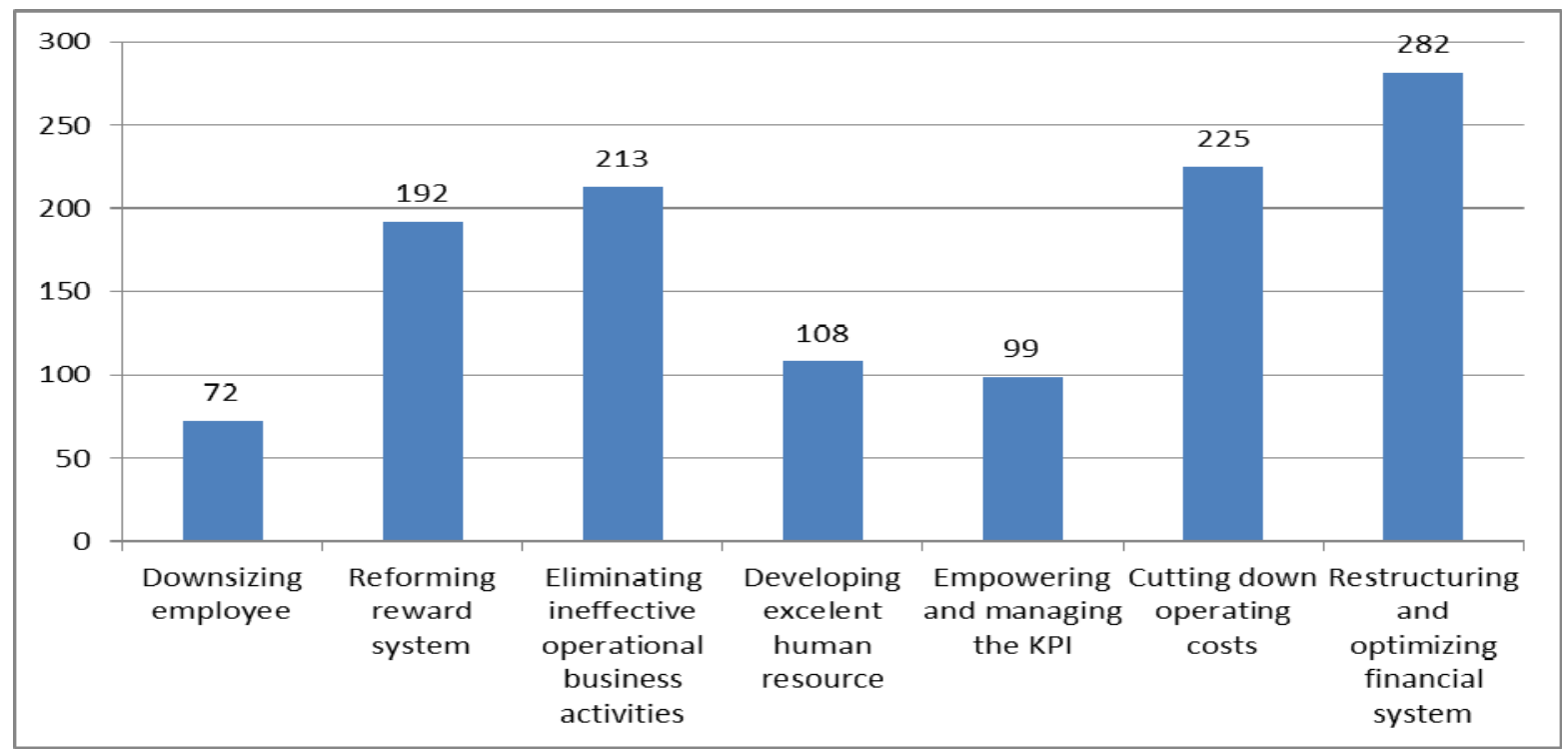

Figure 1. Top priorities in the times of recession $(n=478)$

Source: Author (2013)

\subsection{Leadership competencies}

Firsly, in previous research, Le $(2010,2011)$ strongly emphasized creativity, learning, justice, and influence (leadership skills). However, in the economic crisis in 2012, the result with leaders in recession timeindicated that the three most important qualities of business leaders were focus on sustainable development (43.93\%), working enthusiasm (41.42\%), and willingness to take risks (31.38\%). It seemed that these three qualities were appropriate for business leaders to overcome the recession time. This result also had been found in research of Phung \& Le (2013). Interestingly, in the crisis scenario, the leaders evaluate the necessary of sustainability , it could be a good sign for the economy in Vietnam in future years. 


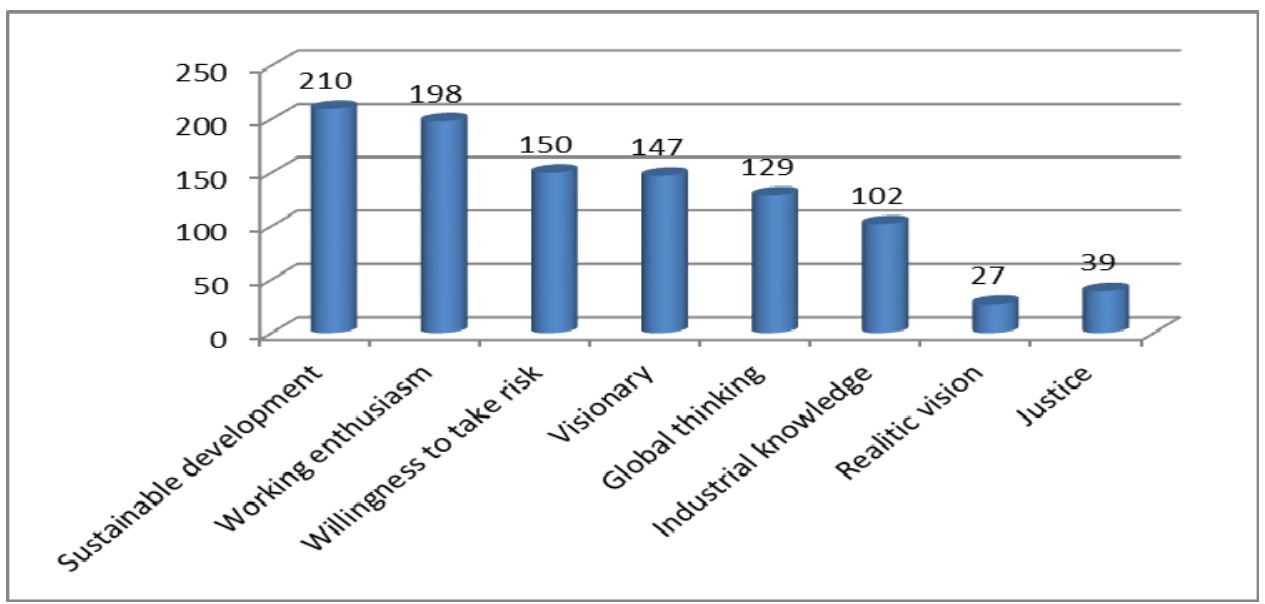

Figure 2. Top priorities in the times of recession $(\mathrm{n}=478)$

Source: Author (2013)

Secondly, in the crisis time, some competence got the second choices included visionary (about 30.75\%), globally thinking (26.98\%) and industrial knowledge (21.33\%). This result means that the leader also highly evaluated some competences which support them to get more opportunities in the future.

Thirdly, realistic vision and pragmatism was probably never featured as highly appreciated. Because the survey limited three qualities that business leaders had to choose from and business leaders would consider only the most important to select. The rise of the quality of vision was pushed up, meaning the other important qualities would be relegated. 4.5 Leaders' competencies assessed by senior managers

In the second survey, senior managers in Vietnamese private enterprises were asked to assess their leaders' competencies. The survey results showed that no leadership competency is assessed as good or excellent level by senior managers. All average values are less than 4.0 and divided into 8 groups of leadership competencies according to the evaluation of senior managers in order of highest overall rating to lowest. As a result, business leaders were reviewed highly on their business positions. Their leadership and human resources management competencies were not appreciated by senior managers. Even in the area of human resource competency, skills that were appreciated better were often about encouraging subordinates to try and learn, rather than about training and coaching subordinates. Business leaders spent little time for subordinates and behaved emotionally and did not establish a performance evaluation system for staff scientifically and fairly. In addition, business leaders were estimated lowly in successor's development.

\section{Discussion and Implications}

According to Phung \& Le (2013), corporate management and governance should be based on a "cool head" rather than a "hot head". The main shortcomings of today's business, besides the external factors, mostly came from downplayed strategic management, underestimated risk management and operational management (finance, human resource, marketing, production...). To be able to survive and develop in the future, enterprises should enhance their internal management system (human resource management, financial management...). In order to do that, that corporate investment should start from guaranteeing leadership qualified and proficient due to the fact that leadership increasingly turns out to be leverage for business development in future. By the way, promoting leadership always sticks tightly to a capable leader.

As previously mentioned, the business leaders' psychology should be recognized with caution because it may affect their ability to recognize and seize opportunities. As a result, final decision, especially selected corporate strategy can be affected. It is often believed that building self-confidence in new business environment is more preferable in this paper. They should consider the economic crisis as both challenge and opportunity. Thus, Vietnamese enterprises should define long-term competitive advantages on the basis of spending time and effort to prepare the 
next steps for the next 3 years within the crisis. The economic cycle is increasingly short in span - from 2 to 3 years. Therefore, positive managerial thinking is actively exploiting the economic crisis as a treatment phase, preparing the foundation for the next stage.

Responding to low expectation about future economic prospect, Vietnamese leaders had a tendency to adopt shortterm and reactive actions towards recession as analyzed in the study of Lovelock (1997) (e.g. cutting down operation costs, restructuring and optimizing financial system, eliminating ineffective business activities), rather than longterm and proactive strategies to seize opportunities from recession (e.g. seeking new market, taking advantages of new opportunities). This result could probably be a suggestion for Vietnamese leaders to improve their leadership performance. It could possibly be recognized that Vietnamese private enterprises' leaders seem to be quite passive in dealing with adverse external difficulties and have not well prepared to make innovation, find new market or seize opportunities from crisis. Thus, they have tendency to act differently from others in the world and choose strategies that is more feasible but less risky. It is likely that the gap between working environments, internal instinct and thinking habits... create the variety of people's decisions in each region. In fact, their strategies are now accommodating with new business environment in Vietnam where less adverse effects from global crisis have been witnessed. Whatever the priority the leader chooses is, the most important thing is to determine a differentiated and focused strategy. During the growing phase, profit might be sought from various places and sources. Therefore, business leaders need to identify clearly strategies and emphasize on their consistency and efficiency.

The survey's results about the three most needed qualities of business leaders do support the study of Orr \& Sack (2010), which also indicated that working enthusiasm is one of the competencies, beside creativity, that leaders may lack. As a matter of fact, leaders' competencies is not highly appreciated by senior managers as they saw their leaders as lacking important leadership competencies recognized in former studies, such as human resources management, developing others and encouraging -them on a fair basis. Business leaders should focus on selftraining actively. Besides, only when business leaders organize their work well, have good leadership and good management systems, business will attract, use, and develop capable people. A business leader with poor competencies will find it difficult to attract and use talent as well. The current economic situation is extremely difficult for all businesses, especially private enterprises because they are fundamentally vulnerable to and have restricted control over external environment. In order overcome this difficult stage, the good leaders become necessarily important. However, they cannot work by themselves alone while the whole society, especially of the government agencies is supposed to joint their hands. Above suggestions is believed to contribute in keeping Vietnamese enterprises' survivals, and create a leverage for their future development as the recession time is over.

\section{Conclusion and Suggestions for Future Research}

This study achieved its research purposes of analyzing Vietnamese private enterprise leadership in the context of global economic recession and making comparison with on-going experiences from many studies in the world. From that, the study concluded some notable implication from empirical leadership in Vietnam with hope of enhancing efficiency of Vietnam leadership as well as business performance.

The study shows a strong psychological effect of recession on Vietnamese business leaders as they had a relatively pessimistic outlook at the economic prospects within the two coming years of most private enterprise leaders. Prior business objectives shifted from increasing growth to higher quality and safety, leading to cautious decision and restrictions in investment. For example, risks in policy changes and the environment had great pressure on the decisions of business leaders. This might affects the leader's final decisions, then business performance and possibly lead to investment flows of foreign enterprises to reduce in the near future if the government did not quickly have measures to improve the business environment.

While being fairly pessimistic about the economy in the next years, Vietnamese business leaders agreed that there were so many challenging problems during recession time, especially the increasing complexity of business environment, risks of government policy changes...

However, there are numerous weak skills of Vietnamese business leaders, especially managerial skills such as training, subordinate guidance, and developing high-quality human resources. As the systematic operation is not good, corporation hierarchy cannot be developed. The obvious consequence is that the enterprise will have a difficulty in attracting talent or skilled employees. Accordingly, they need to access to better management, improve 
Asian Social Science; Vol. 10, No. 9; 2014

ISSN 1911-2017 E-ISSN 1911-2025

Published by Canadian Center of Science and Education

themselves competencies and clearly determines what challenges they could face and what responses they should do. Most importantly, the rational attitude should be the confidence in the economic recovery and the success based on seizing opportunities from the hardship.

Managerially, the research results are incredibly meaningful to business leaders, supplementing worldwide knowledge and experiences about leadership, revealing several weaknesses that they have not recognized before and providing an opportunity to reconsider and evaluate corporate administration. This study also helps to increase business leader's confidence in future and their attention to macroeconomic forecast, risk management and greater flexible adaptation.

Not only managerial contribution but this paper also acts as supplementing material to the rich literature related to this area, especially in Vietnam. Today's studies seem to not access closely to what leader is thinking given that they have extremely important roles. Furthermore, many researchers are concluding a variety of policy suggestions to improve leadership effectiveness; however, they seemingly ignore the interaction between those policies with the one who directly manipulate the corporation - the leaders. Therefore, expected results from those policies sometimes have not been presented yet. Accordingly, organizations and government, policy makers should consider all predicted findings in this study to enact policy adjustments. Hopefully, above recommendations can become references for them to improve the leadership and effectiveness of Vietnamese private enterprises. Roughly speaking, government agencies should raise their roles in guiding private companies to adapt to the modern world where business's success mainly come from its dependence on customer; therefore, not only efforts of product and service innovations, optimism about future with concentrated strategy but also active human enhancement are more put in priorities.

However, there were some limitations while completing this study. One inevitable limitation is that the study only relies on e -invitations sent separately to more than 1000 CEO of SMEs and more than 10.000 HR Managers, but not interview, telephone. This sole method of data collection limits the results of investigation. In addition, the findings are based on research undertaken with Vietnamese private enterprises in a specific metropolitan area of Vietnam and, as such, there is limited scope for generalization beyond this area. Further research could compare the responses of SMEs in rural area with metropolitan areas. In brief, others should survey larger number of business leaders and targeted enterprises, include more collection methods. Because a larger, more balanced sample and diversified methods will ensure generalizability and incredibility of research's findings.

\section{References}

Athey, G. (2009). Economic Development in the UK: Challenges during and after the Recession. Local Economy, 24 (6-7), 604-611. http://dx.doi.org/10.1080/02690940903353918

Beaver, G. (2007). The strategy payoff for smaller enterprises. Journal of Business Strategy, 28(1), 11-17. http://dx.doi.org/10.1108/02756660710723161

Beaver, G., \& Ross, C. (1999). Recessionary consequences on small business management and business development. Strategic Change, 8(5), 251-261. http://dx.doi.org/10.1002/(SICI)10991697(199908)8:53.0.CO;2-N

Bolman, L., \& Deal, T. (1997). Reframing Organization: Artistry, Choice and Leadership (2nd ed.). San Francisco: Jossey - Bass

Boyatzis, R. E. (1982). The Competent Manager: A model for effective performance. New York: Wiley.

Burnett, J. (2002). Managing business crises: From anticipation to implementation. Westport, CT: Quorum Books.

Chow, M. J., \& Dunkelberg, W. C. (2011). The Small Business Sector in Recent Recoveries. Business Economics. 46(4), 214-228. http://dx.doi.org/10.1057/be.2011.23

Churchill, N. C., \& Lewis, V. L. (1984). Lessons for small business from the recession. Journal of Small Business Management, 22(2), 5-17.

Clark, G. (2009). Recession, recovery, and reinvestment: The role of local economic leadership in a global crisis, OECD, Paris 
Asian Social Science; Vol. 10, No. 9; 2014

ISSN 1911-2017 E-ISSN 1911-2025

Published by Canadian Center of Science and Education

Cuban, L. (1988). The managerial imperative and the Practice of Leadership in Schools. Albany, NY: SUNY Press.

Cuong, T. T., Sang, L. X., \& Anh, N. K. (2008). Vietnam's Small and Medium Sized Enterprises Development: Characteristics, Constraints and Policy Recommendations. In H. Lim (Ed.), SME in Asia and Globalization, ERIA Research Project Report 2007-5 (pp. 323-364). Retrieved from http://www.eria.org/Vietnam\%E2\%80\%99s\%20Small\%20and\%20Medium\%20Sized\%20Enterprises\%20Deve lopment_Characteristics\%2C\%20Constraints\%20and\%20Policy\%20Recommendations.pdf

Dai, G., Tang, K. Y., \& De Meuse, K. P. (2009). The Leadership Architect 2009 global norms report I: Competency norms and analysis technical report. Minneapolis: Lominger International: A Korn/Ferry Company.

Denis, J., Lamothe, L., \& Langley, A. (2001). The dynamics of collective leadership and strategic change in pluralistic organizations. Academy of manage Journal, 44(4), 809-837. http://dx.doi.org/10.2307/3069417

Dutton, J. E., \& Jackson, S. E. (1987). Categorizing strategic issues: Link to organizational action. Academy of Management Review, 12(1), 76-90.

Egan, V., \& Tosanguan, P. (2009). Coping Strategies of Entrepreneurs in Economic Recession: A Comparative Analysis of Thais and European Expatriates in Pattaya, Thailand. Journal of Asia Entrepreneurship and Sustainability, 5(3), 17 -36.

Garcia, H. (2006). Effective leadership response to crisis. Strategy and Leadership, 34(1), 4-10. http://dx.doi.org/10.1108/10878570610637849

General Statistics Office (GSO) of Vietnam. (2010). The enterprises in Vietnam 9 years at the beginning of century 21. Statistic Publishing House.

Hofer, C. W. (1980). Turnaround strategies. Journal of Business Strategy, 1(1), 19-31. http://dx.doi.org/10.1108/eb038886

Kambil, A. (2008). What is your recession playbook? Journal of Business Strategy, 29(5), 50-52. http://dx.doi.org/10.1108/02756660810902341

Kitching, J., Smallbone, D. Xheneti, M., \& Kasperova, E. (2011). Adapting to a Fragile Recovery: SME Responses to Recession and Post-Recession Performance. Paper presented at the 34th Institute for Small Business and Entrepreneurship (ISBE) Annual Conference: Sustainable futures: enterprising landscapes and communities; 910 Nov 2011, Sheffield, U.K.. 9-10 November

Latham, S. (2009). Contrasting strategic response to economic recession in start-up versus established software firms. Journal of Small Business Management, 47(2), 180-201. http://dx.doi.org/10.1111/j.1540627X.2009.00267.X

Le, Q. (2012). Using ASK Model to evaluate quality of business leaders in Vietnam. Journal of Business and Economics, 28, 29-35.

Le, Q. (2010). Sales management. Statistical Publishing House.

Lester, D. L., Parnell, J. A., Crandall, W., \& Menefee, M. L. (2008). Organizational life cycle and performance among SMEs: generic strategies for high and low performers. International Journal of Commerce and Management, 18(4), 313-330. http://dx.doi.org/10.1108/10569210810921942

Lovelock, C. H. (1997). Fear of a recession: The best way to deal with it is to prepare for it. Marketing Management, 6(3), 14-16.

Orr, J. E., \& Sack, K. (2010). Setting the stage for success: Building leadership skills that matter. Minneapolis: Lominger Business HorizonsInternational: A Korn/Ferry Company.

Pearce II, J. A., \& Michael, S. C. (2006). Strategies to prevent economic recessions from causing business failure. Business Horizons, 49(3), 201-209. http://dx.doi.org/10.1016/j.bushor.2005.08.008

Pettigrew, A. M., \& Whipp, R. (1991). Managing Change for Competitive Success. Oxford: Blackwell. 
Asian Social Science; Vol. 10, No. 9; 2014

ISSN 1911-2017 E-ISSN 1911-2025

Published by Canadian Center of Science and Education

Price, L., Rae, D., \& Cini, V. (2013). SME perceptions of and responses to the recession. Journal of Small Business and Enterprise Development, 20(3), 484-502. http://dx.doi.org/10.1108/JSBED-04-2013-0057

Phung, N.X., \& Le, Q. (2013). Leadership in Times of Recession: An Empirical Research of Private Enterprise Leadership in Vietnam. VNU Journal of Economics and Business Vol. 29, No. 2 (2013) 75-86

Rae, D., Price, L., Bosworth, G., \& Parkinson, P. (2012). Business Inspiration: Small business leadership in recovery, 26 (6). Industry \& Higher Education, 473-489. http://dx.doi.org/10.5367/ihe.2012.0125

Shama, A. (1993). Marketing strategies during recession: A comparison of small and large firms. Journal of Small Business Management, 31(3), 62-72.

Smallbone, D., North, D., \& Kalantaridis, C. (1999). Adapting to peripherality: A study of small rural manufacturing firms in northern England. Entrepreneurship and Regional Development, 109-127. http://dx.doi.org/10.1080/089856299283227

Srinivasan, R., Rangaswamy, A., \& Lilien, G. L. (2005). Turning adversity into advantage: Does proactive marketing during a recession pay off? International Journal of Research in Marketing, 22(2), 109-123. http://dx.doi.org/10.1016/j.ijresmar.2004.05.002

Stone, J. (1975). Small Business Management in a Recession. Journal of Small Business Management.

Storey, D. J. (2011). Optimism and chance: The elephants in the entrepreneurship room. International Small Business Journal, 29(4), 303-321. http://dx.doi.org/10.1177/0266242611403871

Nguyen, T. Q. (2011). The recent economic efficiency of Vietnamese enterprises. Retrieved from http://english.tapchicongsan.org.vn/Home/Focus/2011/119/The-recent-economic-efficiency-of-

Vietnameseenterprises.aspx

Weick, K. E. (1988). Enacted Sensemaking in Crisis Situations. Journal of Management Studies, 25(4), 305-317. http://dx.doi.org/10.1111/j.1467-6486.1988.tb00039.x

\section{Notes}

Note 1. Enterprises operating in private sectors.

Note 2. According to VCCI, 2009, the private sector was formed under various types of business (collective, private, collective named, limited, joint-stock with or without the State capital).

Note 3. General Statistics Office (GSO) of Vietnam, 2010.

Note 4. Non-state enterprises - including collective, private, limited, joint stock with or without the State capital (GSO, 2010) can be used as replacement for private enterprises.

Note 5. General Statistics Office (GSO) of Vietnam, Statistical Handbook, 2012.

Note 6. The enterprises in Vietnam 9 years at the beginning of century 21, General Statistics Office (GSO) of Vietnam, 2010.

Note 7. General Statistics Office (GSO) of Vietnam, Statistical Handbook, 2012.

Note 8. General Statistics Office (GSO) of Vietnam, 2012.

Note 9. General Statistics Office (GSO) of Vietnam. Available: http://www.gso.gov.vn/default_en.aspx?tabid=508\&ItemID=12488

Note 10. John F. Kennedy quote, 12th April, 1959. Speech at United Negro College Fund in Indianapolis.

Note 11. Cost-cutting strategies: This coping mechanism is preferable in situations where income has declined to about +10 (profit) to -10 (loss) percent of the firm's break-even point. The focus is efficient operations, involving cutting variable costs, such as staff layoffs, rents, and inputs to the firm's products or services Hofer (1980). 
Asian Social Science; Vol. 10, No. 9; 2014

ISSN 1911-2017 E-ISSN 1911-2025

Published by Canadian Center of Science and Education

Note 12. Combination effort strategies: When a firm's income has declined to about -10 (loss) to -50 (loss) percent of its break-even point, combination strategies may be the most appropriate to pursue. This situation would be one in which the loss is extending towards the limits of variable costs Hofer (1980).

Note 13. Revenue-generating strategies: This coping mechanism might be employed if income has declined to about -50 (loss) to -70 (loss) percent of break-even point. The firm should focus on existing products, or variations to existing products that can be introduced quickly. This would also include seeking new markets Hofer (1980).

Note 14. Asset reduction strategies: If the firm's income is more than -70 (loss) percent of break-even point, then asset divestment should be seriously considered, especially if the business is close to bankruptcy Hofer (1980).

Note 15. Data were collected in 2012 and part of data were used in paper Leadership in Times of Recession: An Empirical Research of Private Enterprise Leadership in Vietnam - VNU Journal of Economics and Business Vol. 29, No. 2 (2013) 75-86

\section{Copyrights}

Copyright for this article is retained by the author(s), with first publication rights granted to the journal. This is an open-access article distributed under the terms and conditions of the Creative Commons Attribution license (http://creativecommons.org/licenses/by/3.0/). 